\title{
Themed Section 1: Reclaiming Commitment to Social Justice in Poor Communities
}

\author{
Guest Editor: Mutendwahothe Walter Lumadi \\ https://orcid.org/0000-0003-0121-7386 \\ University of South Africa \\ Lumadmw@unisa.ac.za
}

In this collection of articles (Themed Section 1), we present some of the dilemmas faced by school managers, teachers, learners, parents, and the broader community in their quest to reclaim schools as beacons of hope and possibility. The four articles in this short compendium suggest that there is an increasing distance between educational stakeholders on the ground-school managers, teachers, students/learners and parents - and educational policy makers. Three South African case studies and one Chinese case study are drawn on to make a collective case for educational reforms that might bring to fruition the educational promise of "education for all".

In "Reimagining Community Schools as Beacons of Hope and Possibility in the South African Context", Bruce Damons and Avivit Cherrington use the findings of their respective doctoral studies to argue for "values-driven" community schools. The authors present a case for schools to be seen not merely as places of formal learning, but also as places of social learning. Schools are social units and an integral part of the community in which they function. Arguing against the "deficit definitions" of community schools, Damons and Cherrington present a reimagination of partnerships between communities and schools.

Locating their study in the "nexus of critical discourse analysis" and "ethnography", Jiayi Shi and Peter Sercombe assess the School Consolidation Policy of the People's Republic of China. In their article, "Poverty and Inequality in Rural Education: Evidence from China", the authors reveal the effects of this policy on school children in the village of Jikan, which is in Shaanxi Province, north-western China. The article reviews trajectories and critical junctures shaping educational change in one rural community as an example of broader changes that have been occurring across the country. While education is widely considered among the most important policy instruments to improve economic mobility of learners from disadvantaged socio-

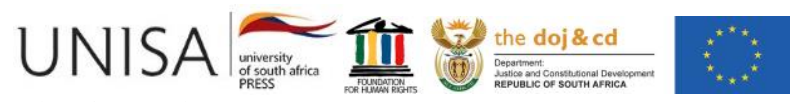

Education as Change

https://doi.org/10.25159/1947-9417/7998

https://upjournals.co.za/index.php/EAC

ISSN 1947-9417 (Online)

Volume 24 | $2020 \mid \# 7998$ | 2 pages

(C) The Author(s) 2020

Published by the University of Johannesburg and Unisa Press. This is an Open Access article distributed under the terms of the Creative Commons Attribution-ShareAlike 4.0 International License (https://creativecommons.org/licenses/by-sa/4.0/) 
economic backgrounds, Shi and Sercombe argue that the Chinese state, with its urban focus, is not succeeding in making prosperity more equitable. In tandem with the idea of "modernity", rural education has become a low priority for the state.

In a departure from conventional "theoretical frameworks", Mutendwahothe Walter Lumadi frames his study, "Fostering an Equitable Curriculum for All: A Social Cohesion Lens", with the injunction, "Education for All". This implies a global commitment to provide quality basic education for all learners. An equitable curriculum, he argues, should empower all learners to "talk back" to the world. Learners must learn to pose critical questions such as: Whose word is final in decision-making? Who is excluded from such decisions, what is the rationale and why? Who stands to gain and who feels the pinch? Why is a given policy fair or unfair? What are its origins? What is required to create change and how can it be addressed? Ultimately, learner work must move outside the school premises, so that scholarly projects are linked to real world challenges.

Rudzani Israel Lumadi, in "Turnaround Learner Discipline Practices through Epistemic Social Justice in Schools", uses an interpretivist qualitative approach to investigate disciplinary practices in a small sample of South African schools. The author explores the impact that discipline has on disadvantaged learners and their families. As part of a disparate impact analysis, the study examines whether frequent disciplinary exclusion from school is educationally justifiable. In contrast to zero-tolerance policies that emphasise punishing instead of positive consequence, Lumadi stresses the need for positive incentives that will motivate learners to behave. When schools develop disciplinary actions, parents should be involved at every stage of the process to obtain their input and to give them a sense of responsibility. 